\title{
Reducing fire risk in buildings: the role of fire safety expertise and governance in building and planning approval
}

\author{
C. M. Benson ${ }^{1} \cdot$ S. Elsmore ${ }^{2}$
}

Received: 27 July 2019 / Accepted: 9 June 2021 / Published online: 24 June 2021

(c) The Author(s) 2021

\begin{abstract}
Following the Grenfell tower incident, fire safety is being re-examined around the world. One key area is planning and building approval. It has been suggested that expert fire authority advice is being ignored in building and planning control. In this paper, freedom of information requests were submitted to fifty local government authorities (covering approx. one quarter of the England and Wales population), and three fire authorities, to examine their consultation process. No prior study has examined this relationship in detail. This work attempts to identify who is assessing fire safety, what expertise exists in the system, and what guidance is available from central government. The impact of austerity on the ability to effectively manage fire safety is also discussed. Results show local government authorities have a large degree of discretion with no guidance from central government on fire safety expertise needed to assess non-prescriptive building standards, and only limited guidance on how fire authority advice should be used by local government. The result is a dramatically different level of engagement of fire authorities, and implementation of fire safety advice. There does not appear to be any guarantee that fire expertise is being employed for the purpose of fire safety in building/planning processes. This means the building regulatory regime may be one of the many issues contributing to fire safety issues. Stronger legislation is required to prevent a post-code lottery of fire safety implementation.
\end{abstract}

Keywords Fire safety $\cdot$ Planning $\cdot$ Building control $\cdot$ Fire engineering $\cdot$ Safe housing

\section{Introduction}

At just before 1 am on 14th June 2017 a fire started in a 23-storey tower block in London, called Grenfell Tower. The fire started on the fourth floor, but by 3am it had spread to most of the building. The Fire Service struggled to respond to a fire of this magnitude and fire

C. M. Benson

bensoncb@1sbu.ac.uk

1 Explosion and Fire Research Group, School of Engineering, London South Bank University, 103 Borough Rd, London SE1 0AA, UK

2 School of Law and Social Sciences, London South Bank University, 103 Borough Rd, London SE1 0AA, UK 
spread of this speed. The disaster resulted in the deaths of 72 people (BBC News, 2019). As immediate causes were being explored, such as materials used, compartment failure and evacuation policy, systemic barriers and management failures of the incident also attracted attention. Several observations emerged that neoliberalism, which had brought with it decades of privatisation, deregulation and cuts in public funding had created a climate within which this fire could happen: "the neoliberalisation of the British housing market, it was argued, had created a dangerous climate in which local authorities were incentivised to neglect the needs of their less well-off residents, and choose to put costs and profit before health and safety" (Danewid, 2019, p. 2).

Fire services have seen significant budget cuts since the introduction of austerity governance measures following the financial crisis in 2007-2008. As Murphy (2015) has detailed, budgets have been cut between 26 and $39 \%$, with a reduction of $25 \%$ in fire safety officers (McIntyre, 2017). Wheeler (2015) has reported that direct grants to local government fell by $27 \%$ between 2011 and 2015. In London, for example, the London Fire Brigade (LFB) has been required to make savings of over $£ 100$ million since 2009-2010, achieved mainly through back office cuts, including fire safety and engineering staff (Mayer, 2016).

Following this tragedy at Grenfell Tower, serious questions were posed about the regulation of fire safety in high-rise buildings by the government, engineers and architects, both in the UK (United Kingdom Prime Minister's Office, 2017; Greater London Authority, 2017; RIBA, 2017) and around the world (Farrugia, 2021; IEAust, 2017; Verzoni, 2017). Since 2017, at least 434 buildings with similar cladding issues have been identified (MHCLG, 2019), as well as a reported additional 1375 buildings with other inappropriate cladding types (Ellson, 2020), indicating the potentially severe nature of fire safety issues, which could be understood to reflect a failing system. Questions have been raised on other areas of fire safety on, for example, the use of sprinklers in high rise buildings, the different height thresholds for required sprinkler introduction in the UK nations $(30 \mathrm{~m}$ in England and Northern Ireland, $18 \mathrm{~m}$ in Scotland, and $0 \mathrm{~m}$ in Wales), and the lack of backdating of these safety requirements to older buildings.

Failures identified in the first stage of the government enquiry in relation to the building include use of uPVC (nplasticized polyvinyl chloride) window fittings and extractor fans that allowed breach of compartmentation through deformation, and insufficient fire doors and door closers (Moore-Bick, 2019). One of the most discussed failings relates to the use of flammable cladding on the outside of the building. Moore-Bick (2019) notes that, contrary to building requirements, the cladding materials "did not adequately resist the spread of fire having regard to the height, use and position of the building. On the contrary, they actively promoted it" and because of these issues goes on to say, "there was compelling evidence that the external walls of the building failed to comply with Requirement B4(1) of Schedule 1 to the Building Regulations, 2010”.

The tragedy at Grenfell exposed fundamental questions about both the role and enforcement of building regulations in England and Wales, and the necessity to reform these. This despite calls a decade earlier following the fire at Lakanal House in Southwark for the need to address building regulations (Hodkinson, 2018). Hackitt's (2018) independent review of Building Regulations and Fire Safety sought to examine the UK's legislation, regulation, and inspection regimes, which exposed a series of problems with the system, described as facilitating a "race to the bottom" and ignoring quality. One area dealt with fleetingly by this report is that the advice given by fire authorities is being ignored or disregarded within the building and planning process. Under the current system in England and Wales, fire authorities are the only experts required to advise on fire engineering safety, related to their role as enforcement agents for fire safety once a building is occupied, and in practice they 
are often the only fire experts involved. These reports proved deeply concerning. Indeed, the former Department for Communities and Local government report noted in 2012 that fire services are at times "unhappy with what the building control body has approved, but they have accepted it, noting their concerns in their consultation response" (Aecom, 2012, p. 34).

This has raised serious issues in terms of the governance, expertise and competence deployed to manage fire safety processes; particularly whereby discretion can operate within approval processes for building and planning control (Hackitt, 2018). Several key questions then emerge within this context, such as: who is assessing the suitability of buildings in England and Wales? Is there sufficient regulation and guidance provided by central government to govern fire safety? Are experts involved in these consultation processes? Are those assessing the suitability of building fire safety competent to do so? Is there any guidance on expertise required to govern fire safety?

Through a series of Freedom of Information (FOI) requests this paper draws attention to the nature of the consultation relationship between local fire authorities and local authority building and planning control in their governance and assessment of fire safety. This paper will highlight how the modern building regulatory regime is one of many issues affecting fire safety and could be contributing to serious fire deficits. The paper begins in Sect. 2 by detailing building and planning regulations in England and Wales, before attending to the importance of addressing the impact of neoliberal restructuring of the local state, as successive waves of public policy have sought to systematically restructure the UK state, from New Labour's modernization agenda to the more recent deployment of austerity governance by the Coalition Government.

Following a discussion of the methodology deployed in Sect. 3, the paper proceeds in Sect. 4 to draw upon an analysis of FOI requests from the three largest UK city authorities-Greater London, Greater Manchester and the West Midlands, to illustrate the range of multiple and often insufficient systems that operate and fill the void when a lack of guidance is provided by central government to assess fire safety for building and planning control, and the failure to properly deploy expertise within these domains. The paper contends that a lack of governance exists in relation to fire safety, as discretion and a lack of guidance from central government produces limited advice on how fire authority advice should be used by local authorities. With differing levels of engagement and implementation of fire safety advice emerging, this raises concerns about the deployment of competent expertise and the implications of this for fire safety within new developments. The final section of the paper reflects on these findings and considers avenues for future work needed to address this pressing issue.

\section{Building and planning regulations in England and Wales}

Planning and building control in England and Wales operate through different processes. Developers may require one of both processes for approval. A simple diagram of this system can be found in Fig. 1. Depending on its size and impact, planning approval will be required for the wider impact on residents and the area and building approval for the technical assessment of the building design, materials, and construction (Planning Portal, 2006). While local planning authorities do not possess powers or responsibilities in terms of the fire safety of both buildings and material used, local planning authorities might opt to confer with the local fire authority in relation to matters such as fire engine access or the 


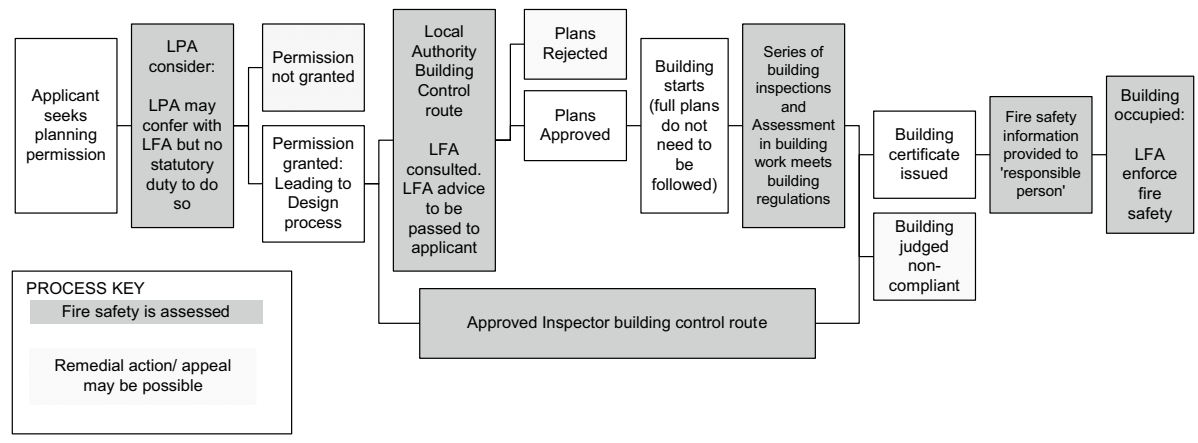

Fig. 1 A flowchart showing a simplified representation of planning and building approval processes in England \& Wales in relation to fire safety (drawn from information in Appendix D, Hackitt 2017)

visual impact of materials such as cladding (RTPI, 2017). As such, there is no statutory duty for the Local Authority Planning Control (LAPC) to contact the Local Fire Authority (LFA).

Building fire safety In England and Wales is governed by the Building Regulations, 2010 (under Building Act, 1984). Building regulations are supported by 'Approved Documents' setting out the standards seeking to secure the health and safety of people in or surrounding a building (Planning Portal, 2006), with Approved Document B addressing fire safety, including, escape, warning, fire spread and firefighting. Alternative approaches such as British or European standards, such as BS9991 2015 may also be used, if it is judged by the approving local authority that the building regulations have been met. While these are commonly referred to as building fire safety regulations in England and Wales, in practice they are a set of guidelines and standards that can be used in an holistic manner to demonstrate compliance with the Building Regulation 2010 legislation (Hackitt, 2018).

The role of local authorities in building control is prescribed in Building Regulations and Fire Safety Procedural Guidance 2015. Building control bodies are responsible for checking compliance and have a statutory requirement to consult with the LFA and search for "mutually compatible views on whether ... work is satisfactory" (DCLG, 2015, p. 18). This guidance does not stipulate what action must be taken by Local Authority Building Control (LABC) on its receipt (other than to inform the applicant), or how to decide what to do where LFA and LABC views are incompatible.

Building regulation adherence can be assessed by one of two routes: through LABC; or privately hired "approved inspectors". There have been suggestions that the use of private inspectors is regulatory capture in that the use of private inspectors who derive income based on repeat business is a conflict of interest (Hackitt, 2018). This again raises concerns surrounding governance, regulatory adherence and expertise in building approval systems, however, due to the availability of data through the Freedom of Information Act, 2000 this work will primarily examine the local authority route. Planning control is purely in the local authority domain.

Once occupied building fire safety is legislated by the Regulatory Reform (Fire Safety) Order (RRFSO) 2005. With a series of specific requirements in relation to risk assessments etc., it broadly states the 'responsible person' (i.e., person having overall responsibility for that building) should take precautions to protect employees (and other relevant building users) and, take reasonable fire precautions to ensure that the premises are safe. 
This is normally enforced by the LFA. The RRFSO 2005 repealed or revoked several other national and local legislation including the Fire Precautions Act, 1971 and sections of local acts such as the Greater Manchester Act, 1981. In turn, this has shifted the responsibility for the regulation and enforcement of fire safety from the fire authority to the individual.

The Fire Precautions Act required the fire service or local authority to issue a Fire Certificate for certain classes of premises. In practice, therefore, the certificates would not be issued (and thus a building could not be occupied) until the LFA was happy that the building met their standards of fire safety. However, under the new legislation, there is no certification process by the LFA prior to occupation (beyond some licensed premises), and the building may be occupied without meeting all these safety concerns. Thus, local authorities are granted a large degree of autonomy, and furthermore extends the agenda around selfregulation in the context of building regulations.

There is also evidence that the use of Approved Document B as a 'prescriptive baseline' of safety has also been problematic, with different interpretations being used where there is a lack of fire engineering consultation. A key example is the different understanding of flammable cladding use. The UK government has said, post-Grenfell, that cladding materials are covered by the term 'filler' in (what was formerly) Sect. 12.7 of the Approved Document B 2010 (DCLG, 2013), where; (DCLG, 2017) which stated:

"In a building with a storey $18 \mathrm{~m}$ [etres] or more in height....any insulation product,

filler material (not including gaskets, sealants and similar) etc. used in the construction of an external wall should be of limited combustibility or better".

However, industry professionals have said that they do not recognise cladding core material as 'filler', with Lane (2018, F1.2.16) stating they could not locate any attributable industry definitions of the core material as filler before the Grenfell incident. The lack of scrutiny and fire safety expertise has resulted in a departure from what the government argues is the intention of the Approved Document B. This appears to be one reason flammable cladding is being used on the outside of buildings.

In Europe several different processes are used. Across Germany fire safety regulations are largely defined federally (based on a national code, but with local variation), and use a prescriptive process (CFPA, 2018). De Castella (2017) reports that in France public and high-rise buildings are subject to an approval process by a technical panel including engineers and firefighters, attempting to ensure that the safety concerns are carefully considered. Countries such as Germany, Croatia and the Czech Republic have forbidden flammable components on building facades, while other countries such as Netherlands and Greece instead look at the combined façade behaviour (Harris, 2017). It is clear from the differences that no best-practice standard is recognised widely. It is arguable that both methods could be used simultaneously, with perhaps different tiers of building complexity requiring scrutiny where they depart from building regulations, however any process that removes scrutiny by properly qualified fire, and other, engineers would be inherently more risky.

\subsection{Restructuring fire regulations and fire safety}

Following the tragedy at Grenfell Tower, serious questions were posed about the regulation of fire safety in high-rise buildings in the UK, and importantly, about the context within which such a fire had been able to happen. As Hodkinson (2018) asserts, careful attention needs to be paid to the 'political decisions' that have shaped successive waves of public policy as part of the systematic restructuring of the UK state, and how this has 
subsequently translated into fire regulations and their enforcement. Within the privatised model that has come to determine how both social housing and the broader built environment are delivered he argues, "the disaster exposed a much deeper neoliberal-fault line in the governance of housing safety, from decades of so-called 'free market' policies aimed at boosting capitalist profitability...Accompanying privatisation and outsourcing has been a dangerous game of deregulation in which both legal standards governing building and housing safety and their enforcement have been fundamentally weakened" (Hodkinson, 2019, pp. 5-6).

The ideological rooting of neoliberalism as a "framework of disciplinary political authority that enforced market rule over an ever wide range of social relations throughout the world economy" (Brenner \& Theodore, 2002, p. 14), has fundamentally shaped decades of public policy decisions in the UK; as successive attempts to systematically restructure the UK state has sought to move the Fordist collective state, towards more flexible and privatised forms of welfare provision and support (Peck \& Tickell, 2002). Within these processes of state restructuring, local government has become a key site of reform, as Ward et al., (2015, p. 444) remarks,

'the local state has simultaneously been the site and target of sweeping programmes of institutional restructuring aimed as catalysing supposedly latent potentialities for economic growth' (Ward et al., 2015, p. 444).

While Jessop (2002) suggests that neoliberalism seldom exists in its unadulterated form, but rather can be deployed to as a way to understand Brenner et al., (2010, p. 183) refer to as the 'bewildering array of forms and pathways of market-led regulatory restructuring across places, territories and scales'; Cochrane importantly asserts that 'local government...was a key site across which the process of neo-liberalization was realized in practice, not through the imposition of some preordained template but through complex processes of negotiation, accommodation and sometimes resistance' (Ward et al., 2015, p. 451).

This was evident in the project to modernise local government and public services from 1997 onwards following the election of the New Labour Government. Ushering in a joined-up approach to policy and delivery, encouraging collaborative working across the public sector, New Labour sought to improve the performance and efficiency of local authorities (Downe \& Martin, 2006). By introducing a whole host of performance management regimes, New Labour sought to improve locally delivered services in England and Wales and change the relationships between central and local government (Downe \& Martin, 2006).

While fire and rescue services were not immediately the subject of the modernisation agenda, by 2005 they had become fully embedded within New Labour's public reform agenda, through the Fire and Rescue Act 2004, the introduction of the Integrated Risk Management Planning process, and by bringing fire and rescue services into the Comprehensive Performance Assessment Regime (Murphy \& Greenhalgh, 2017). The modernisation of local government and public services was also accompanied by the government's programme to create and encourage Better Regulation, which sought to adopt a risk-based model to regulation shifting the responsibility towards self-regulation and self-certification (Hodkinson, 2018). For fire safety enforcement, this become firmly embedded in England and Wales following the introduction of the RRFSO 2005, as discussed in the previous section, in some ways expanding the self-regulation begun under the Thatcher government in the Building Act, 1984 (Ley, 2004). 
The post-2010 governing landscape in the UK was accompanied by serious concerns about tackling the UK's budget deficit and the levels of National Debt resulting from the global financial crisis in 2007-2008 (Bailey et al., 2015). Fire services were not immune from such cuts, with budgets cut between 26 and 39\% (Murphy, 2015). Following the election of the Conservative-Liberal Democrats Coalition Government in 2010, decisions were quickly taken to deal with the deficit. Cuts to public services lay at the heart of this, as the Coalition Government adopted a 'fast and deep' approach to cutting public services. The October 2010 Spending Review declared $£ 30$ billion in reductions to public services over the following four years (Lowndes \& Pratchett, 2012), which paved the way for significant changes to the spending review, budget, and audit and accountability arrangements for the public sector (Spencer et al., 2018).

The Coalition Government ushered in their flagship Localism Act in 2011 to supposedly free local government from central and regional control (Featherstone et al., 2012). Seeking to rebalance the relationship between central and local government and devolve power to local communities, these reforms were presented as a way of enabling local authorities to act in the interests of their communities (Bailey et al., 2015). This agenda sought to transfer power to locally elected politicians, and to enable communities to have greater levels of control, to reform governance arrangements in favour of the local as the idealized site of governing (Deas, 2013). By promoting localized modes of governance, this represented a process of down-scaling, while placing responsibility firmly at the local level (ibid). This was further accompanied cuts to perceived red tape in terms of regulation by abolishing the Audit Commission, and relinquishing performance management frameworks and performance audits, resulting in less of a focus on service outputs and outcomes, and more on 'financial conformance' (Ferry \& Murphy, 2018; Timmins \& Gash, 2014).

Whilst the Localism reforms provided local authorities with greater independence over spending decisions, this has not granted local government with greater capacities to generate revenue (Spencer et al., 2018). As Stoker (2011), in Lowndes and Pratchett (2012), has warned, "we are being offered an anti-state vision of localism, a particular ideological brand rather than an expression of a consensual commitment to decentralisation". This "downsizing of the state" has therefore been fundamentally underpinned by a strong focus on ushering in an era of austerity, as the post-war welfare social protection has continued to be dissolved in favour of free markets and individual responsibility (Krugman, 2012). As Newman (in Ward et al., 2015) contends, local governments have become increasingly weakened by continued swathes of budgetary cuts and local state retrenchment seeking to decrease its powers. Profound changes to the UK welfare state have occurred under this neoliberal agenda, as responsibilities are being shifted from central government, to local government, the voluntary sector and individuals (Bailey et al., 2015).

As Bailey et al. (2015) highlight, it is essential to distinguish between the economic and fiscal problems and the solutions implemented to solve this, with austerity policies needing to be understood as a political choice, rather than unavoidable solution. Lowndes and Pratchett (2012, p. 38) warned early on, "as the impact of the cuts (along with the wider costs of recession) undermine the prospects for all but the most affluent communities, it seems probable that localism will leave the majority of councils not waving but drowning" (Smith, 1957). Rather than understanding this necessarily as an inevitable political decision, such changes must be situated within the broader successive neoliberal restructuring of the local state, whereby austerity governance has been deployed a rationalisation to justify cutbacks in funding and attempting to downsize the role of the state. As Penny (2017, pp. 1358-9) importantly identifies, 
'local government is once again being used to absorb and resolve the crisis tendencies of neoliberal capitalist accumulation and uneven development through local governance innovation...the extent and nature of fiscal disciplining today deepens and broadens the scope and scale of neoliberal local state restructuring.'

Short-term cutback management has therefore become a principal concern for local authorities and fire and rescue services within these broader structural transformations (Jones, 2017, in Spencer et al., 2018).

\subsection{Competence and expertise}

The system for building regulations in England \& Wales is a non-prescriptive, performance-based system. While elements are defined by various industry, national or international standards (e.g., fire doors, fire stopping materials) the (new) building as a whole can be judged holistically. This requires a significant understanding of fire safety, as well as an understanding of the routes to compliance, and how they interact with one another. However, there appears to be little advice at all on who should be doing this work, and what their expertise or competence level should be. In practice many builders use Approved Document B as an effective prescriptive system. However, given the technical content of the document in relation to fire, a lack of expertise (or a requirement for it) in those interpreting the document can equally cause issues in relation to fire safety provision. Which in turn raises serious concerns about how expertise is imagined and to what ends this is being deployed within the context of successive rounds of state restructuring, which over successive decades has seen a shift towards pushing self-regulation and individualised responsibility, particularly for local authorities, in relation to fire safety within building regulations.

There is currently no guidance from central government on the expertise required to assess the fire safety aspect of building or planning processes. Similarly, the RRFSO 2005 states a fire safety assessment must be performed for occupied buildings but there is no definition of what is required in terms of qualifications or experience to perform this task, which creates an opaque landscape when it comes to the necessity for and subsequent deployment of expertise in relation to fire safety. This contrasts with the LFA whose expertise is defined in a competence framework (NFCC, 2015) and similar industry advice (IFE, 2014). In this void, particularly before discussions following the Grenfell Tower disaster, according to Gannaway ${ }^{1}$ (2014), building owners approach to choosing fire safety assessors varied dramatically, resulting in a variety of qualification and experience levels in local authorities (Barratt, 2019). This lack of advice or qualification is unusual in the building industry where competent person schemes are common and recommended by central government (Ministry of Housing, Communities and Local Government, 2018).

By examining who is undertaking the suitability of buildings in England and Wales and their fire safety, attention therefore must be paid to the role of expertise and competency within these assessments. The prioritization of expertise and definition of competence in public organisations can vary dramatically. As Boswell (2017) asserts, to understand the organizational behaviour, we must understand how the organization observes, makes sense of, and responds to its environment.

This raises important questions as to the processes of accountability and transparency arrangements within building regulations and fire safety procedures. Murphy and

\footnotetext{
${ }^{1}$ Peter Gannaway, Chair of the National Social Housing Fire strategy group at time of writing.
} 
Greenhalgh (2013) argued that public sector accountability expanded through performance management measures introduced throughout the late 1990s and 2000s, with the Fire and Rescue Services Act 2004 placing greater emphasis on fire services to be accountable to, not only the risks of property, but also, to that of life (Andrews, 2010).

While Ferry and Murphy (2018) assert that in an era of austerity and severe concerns over the financial stability of local authorities and public services, accountability and transparency measures are fundamental; they argue in reality, accountability measures in England have been weakened, whilst an increase in transparency measures have not been able to substitute this reduction. Indeed, as they remark, "the changes to performance management information in particular have meant that reporting is more partial, scrutiny has become more variable, structures have changed, and quality assurance is receding" (ibid p. 625). This is mirrored across a variety of areas of government and industry by the deregulation agenda (DBIS, 2016) which has resulted in a range of regulation withdrawal, including for health and safety.

Post-Grenfell evidence has begun to cast light on the lack of fire safety work being undertaken (Apps, 2017; Booth, 2017). However, there is limited publicly available information in relation to those assessing buildings during the building and planning control process, or the processes they follow. Thus, calling into question the reality of fire safety procedures within building controls. This paper, using freedom of information requests, seeks to contribute towards this and build a clearer picture, to understand the transparency of these processes, and indeed their accountability in terms of who is undertaking such assessment, and understanding what expertise and competency they possess.

\section{Methodology}

53 freedom of information (FOI) requests have been sent across three English greater metropolitan areas to collect the data for this work. These include all boroughs from Greater London, West Midlands (Birmingham and surrounding districts) and Greater Manchester, shown in Fig. 2. These areas have been chosen as they cover a considerable proportion of the population in England (Approx. one third), are major metropolitan areas (high building density), and because they each have a series of boroughs covered by one LFA; Greater Manchester Fire and Rescue Service (GMFRS); the West Midlands Fire Service (WMFS); and The London Fire Brigade (LFB) for the Greater London Assembly (and prior to April 2018, for the London Fire and Emergency Planning Authority).

FOI requests are a valuable tool for assessing public body processes and interactions because the response has a given background and context, comes directly from the bodies carrying out work and can indicate how data is held at source, increasing transparency and accountability (Worthy, 2010). In the UK a response to an FOI request must be provided within 20 working days from receipt of the enquiry. A public body is not obliged to answer the enquiry, entirely, or in part, if "the authority estimates the cost of complying with the request would exceed the appropriate limit" which for non-central government bodies is set at $£ 450$ (Freedom of Information Act, 2000 S12). The same questions were sent to each borough council (see Table 1).

Where councils responded with a single figure but did not specify whether it was for building, planning or both, this figure has been used as a combined figure, but has also been listed as a proxy for building control numbers (labelled as such in the results section) for comparative purposes. 

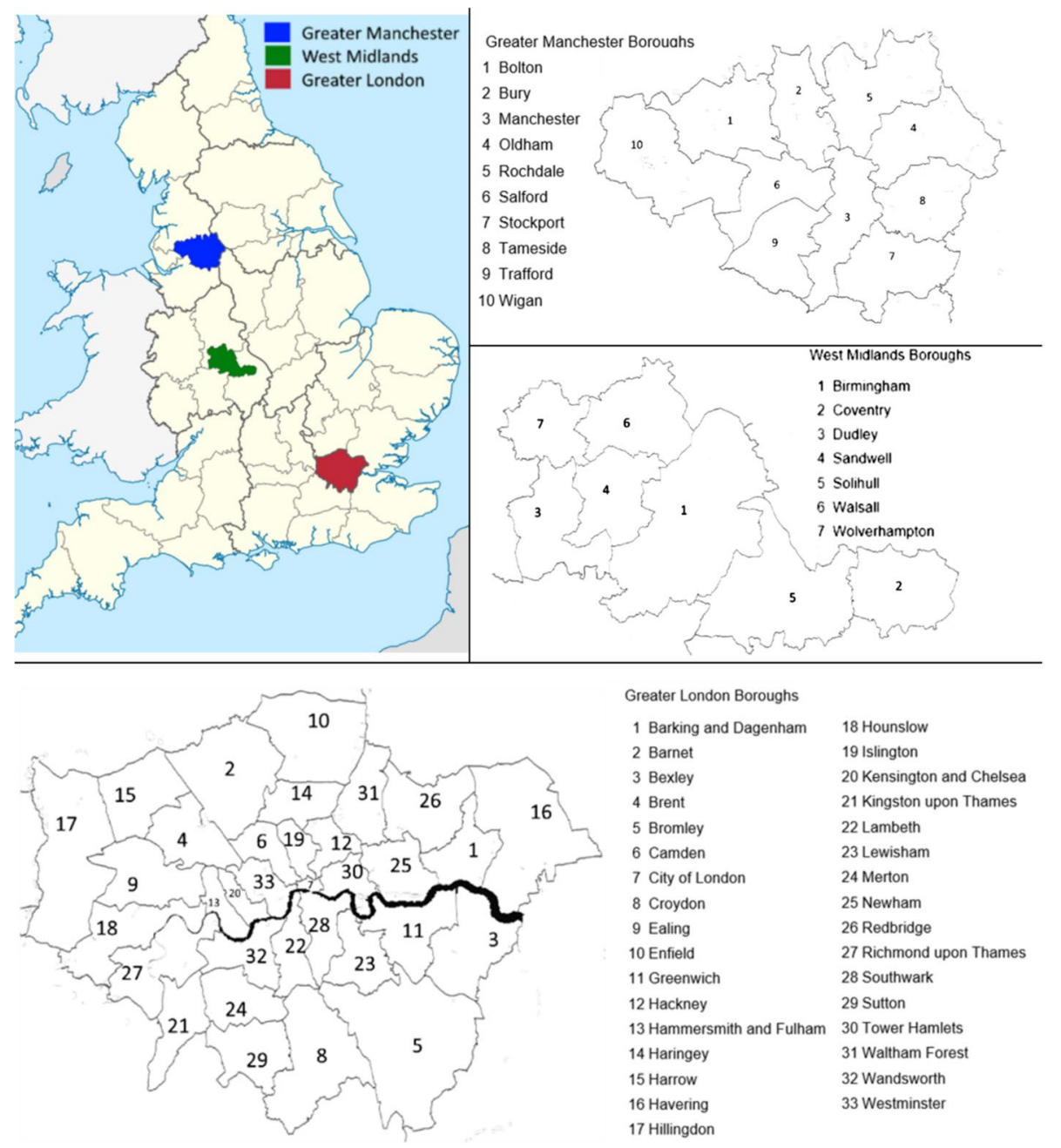

Fig. 2 A series of labelled maps showing the location and boroughs of Greater Manchester, the West Midlands, and Greater London. Map contains Office for National Statistics (2020) Ordnance Survey data (C) Crown copyright and database right

Comparable questions were then sent to each LFA:

- In 2017, how many applications were submitted to you by the Local Authority Planning permission/Building Control departments in your area for comment and advice?

- Could you provide a breakdown of the numbers (i.e., how many applications from each local authority in your area)?

- Do you keep records of the advice you give?

- How many of those applications (2017), in your opinion, did not meet your advised specifications and guidance?

- As far as you know how many applications were granted regardless of your advice not having been met i.e., where a difference of opinion occurred? 


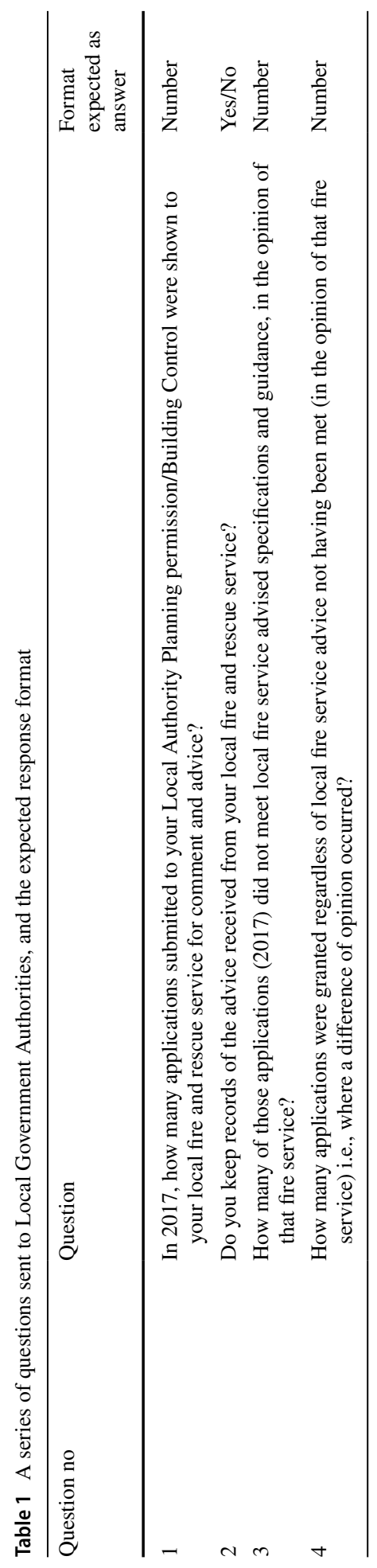




\section{Results and discussion}

This section contains local authority building and planning control FOI request responses. It will then explore the wider impact of the results around governance and competence. It is argued that the current regulatory and organisational regime in England and Wales has resulted in gaps in governance, and appropriate expertise in building and planning processes in relation to fire safety.

\subsection{Response rate}

Of the 50 local government authorities 41 responded within the required 20 working days, with another three responding within one month. Five authorities requested more time, four responding within a further four weeks, and one responding after another three months. One borough, the London borough Kensington and Chelsea, and location of Grenfell tower, failed to respond. Fifty percent of LABC contacted could not or did not answer some, or all, of the questions within the scope of the FOI request; $34 \%$ of LABC contacted did not reveal how many consultations occurred. Another $42 \%$ of all local government authorities contacted were unable to provide information on whether LFA disagreed with approval of projects. This suggests a considerable proportion of local authorities do not have records that allow easy, timely scrutiny of their decision-making processes on fire safety. One LFA responded within 20 working days, one within working 25 days, and the last within six weeks. Each only answered in relation to building control consultations. GMF and WMFS answered three questions, while LFB answered only two.

\subsection{Building control responses}

- Number of consultation applications

Twenty five of $50 \mathrm{LABC}$ were able to provide a numerical answer to this question within the scope of a FOI request; 15 of these in Greater London (50\% response), six in Greater Manchester (60\%), and four in West Midlands (57\%). No pattern in terms of borough size, location (inner/outer city) or wealth could be found (established by comparison with data in the Greater London Authority intelligence Borough profiles). Higher application numbers were associated with higher working age population $\left(\mathrm{R}^{2}=0.57\right)$ and access to transport (public, $\mathrm{R}^{2}=0.58$, and car, $\mathrm{R}^{2}=0.50$ ).

\section{- Records of consultations}

Thirty nine local authorities answered this question with a Yes or No answer. Of these 95\% stated they do keep records of the consultations with the fire services. Five percent (two local authorities) stated they do not keep records of advice from LFAs.

- Q3 Applications meeting fire authority acceptability and Q4 application approvals against recommendations.

Twenty six percent of LABCs (10 Greater London, 3 Greater Manchester) responded to question 3 with a numerical answer. Of those 13 ten LABC record zero objections from LFA, while 3 LABCs (all in London) recorded between 1 and 16 cases. 66\% of LABCs 
provided no answer, 20 citing S12 FOI Act 2000 and four saying data was not recorded as part of the consultation process. Thirty two percent of LABCs responded to question 4 numerically, all saying zero applications were passed despite LFA objections. Fifty two percent of LABC provided no answer. Similar reasons were given (18 citing S12 FOI Act restriction, and 8 not recording that information in their process).

There were a range of interpretations of the $\mathrm{LABC}$ role. Some stated they "never grant an application contrary to the advice of the fire officer".

The majority of those who answered the question had similar positions to:

"We would usually reinforce and promote [LFA] advice, unless there is a fundamental disagreement concerning compliance or if the advice relates to a matter that is not enforceable under B[uilding] reg[ulation]s."

One LABC stated,

"the building control body take on board the views of the fire service, but they are not bound to accept the Fire Authority view. Sadly, it becomes a threshold issue. Each head of service or each owner of an approved inspector will have a different threshold. How risk averse are they and what commercial advantage can I gain by being less risk averse? “

Two respondents appear to say fire service advice has little impact on their role. The first of these states,

"Applications are not referred to the fire service until the building regulations matters are satisfactory. The fire service only gives additional guidance on issues under the on-going [building] control and management".

i.e., the fire authority advice is not sought as part of the building control and building regulation consultation process but as a supplementary activity.

The second of these respondents takes a similar judgement to the process stating,

"The Building Regulation consultation process does not deal with local fire service requirements and is only related to the national Building Regulations. Any additional matters may be communicated directly by the local fire and rescue service to the applicant."

Clearly there are dramatically different interpretations of LFA advice in relation to building control, and its incorporation into the building plan. The combination of nonprescriptive building guidelines and a corresponding lack of clear response protocols from Central government results in a post-code lottery of fire safety implementation. Additionally, far from allowing LABC more power, in some cases they believe they have less. One theoretical example given by a local authority representative, was wanting sprinklers in all schools. The representative made the point that builders are able to reply "but it's only advisory, it's not a requirement". Thus, LABC are unable to insist on safety standards they deem suitable for some public buildings, such as schools, many of which are operated through trusts outside of their control.

- Fire and local authority data comparison

The number of consultations between LABC and LFA is recorded by each of those entities. The data for London (shown in Table 2) is different for every borough. For the London boroughs that do report a value the total number of consultations is 845 . The total 
Table 2 The number of building consultations recorded by local authority building control

(LABC) and local fire authorities (LFA) in Greater London in 2017

\begin{tabular}{lll}
\hline Borough & $\begin{array}{l}\text { Consultations } \\
\text { recorded by LFA }\end{array}$ & $\begin{array}{l}\text { Consultations } \\
\text { recorded by } \\
\text { LABC }\end{array}$ \\
\hline
\end{tabular}

\begin{tabular}{|c|c|c|}
\hline Barking and Dagenham ${ }^{\mathrm{a}}$ & 86 & 29 \\
\hline Barnet & 319 & 45 \\
\hline Bexley & 117 & - \\
\hline Brent & 263 & 7 \\
\hline Bromley & 259 & 63 \\
\hline Camden & 780 & - \\
\hline City of London & 902 & 162 \\
\hline Croydon & 283 & - \\
\hline Ealing $^{\mathrm{a}}$ & 360 & 22 \\
\hline Enfield & 163 & 22 \\
\hline Greenwich & 152 & 71 \\
\hline Hackney & 371 & - \\
\hline Hammersmith and Fulham & 358 & - \\
\hline Haringey & 210 & 73 \\
\hline Harrow & 127 & - \\
\hline Havering & 153 & 40 \\
\hline Hillingdon & 251 & - \\
\hline Hounslow & 265 & - \\
\hline Islington & 447 & - \\
\hline Kensington and Chelsea & 378 & - \\
\hline Kingston upon Thames & 157 & 47 \\
\hline Lambeth & 355 & - \\
\hline Lewisham & 167 & - \\
\hline Merton & 154 & - \\
\hline Newham & 278 & - \\
\hline Redbridge & 147 & 28 \\
\hline Richmond upon Thames & 164 & 17 \\
\hline Southwark & 473 & - \\
\hline Sutton & 159 & - \\
\hline Tower Hamlets $^{\mathrm{a}}$ & 509 & 196 \\
\hline Waltham Forest & 142 & 23 \\
\hline Wandsworth & 301 & - \\
\hline Westminster & 1749 & - \\
\hline Total & 10,999 & 845 \\
\hline
\end{tabular}

- No numerical answer provided by LABC

${ }^{\mathrm{a}} \mathrm{A}$ single answer was provided by these councils. It is unclear if this was a figure for building, planning or both

for the same boroughs, recorded by LFB, is 3986. In total LFB reported receiving 10,999 consultation requests in 2017. With 260 working days in 2017 in the UK this represents 42 requests per day. One possible explanation for the difference is that that local authorities make more than one consultation to the fire service, under one case in their files. Thus, the fire service would record multiple records for a single property. It has been established 
Table 3 The number of building consultations recorded by local authority building control and local fire authorities in Greater Manchester in 2017

\begin{tabular}{|c|c|c|}
\hline & $\begin{array}{l}\text { Consultations } \\
\text { recorded by LFA }\end{array}$ & $\begin{array}{l}\text { Consultations } \\
\text { recorded by } \\
\text { LABC }\end{array}$ \\
\hline Bolton borough & 3 & 15 \\
\hline Bury borough & 2 & 64 \\
\hline Manchester borough & 0 & - \\
\hline Oldham borough & 0 & - \\
\hline Rochdale borough & 0 & - \\
\hline Salford borough & 1 & 70 \\
\hline Stockport borough & 9 & 26 \\
\hline Tameside borough & 3 & - \\
\hline Trafford Borough & 1 & 68 \\
\hline Wigan Borough $^{\mathrm{a}}$ & 18 & 61 \\
\hline
\end{tabular}

${ }^{\mathrm{a}} \mathrm{A}$ single answer was provided by these councils. It is unclear if this was a figure for building, planning or both

Table 4 The number of building consultations recorded by local authority building control (LABC) and local fire authorities (LFA) in the West Midlands

\begin{tabular}{llcc}
\hline & $\begin{array}{l}\text { Consultations recorded } \\
\text { by LABC }\end{array}$ & $\begin{array}{l}\text { Consultations recorded } \\
\text { by LFA }\end{array}$ & $\begin{array}{l}\text { Consultations by LFA } \\
\text { judged as unsatisfactory }\end{array}$ \\
\hline Acivico/Birmingham & 208 & 221 & 8 \\
Coventry & - & 9 & 1 \\
Dudley & 67 & 57 & 5 \\
Sandwell & 54 & 6 & 1 \\
Solihull & - & 29 & 2 \\
Walsall & 237 & 24 & 10 \\
Wolverhampton & - & 40 & 4 \\
& 566 & 386 & \\
\hline
\end{tabular}

on follow-up enquiries that this is the total number of building consultations, including approved inspectors, as LFB do not record these separately. LFB did not keep record of the number of objections to plans submitted for consent and had no record of whether any concerns were met or if the response was unsatisfactory.

For Greater Manchester, the opposite data condition appears. Table 3 below shows that Greater Manchester record very few applications, in comparison to LABC. This might be the failure to record centrally or may be due to advice being sought by LABC at a local level and thus not a centrally recorded location. GMF had recorded 13 applications that did not in their view meet the specifications and guidance but had no record of whether their concerns were met. It was not stated which boroughs these applications occurred in. West Midlands data from LABC and LFA shows closer agreement than other areas (Table 4). However, there are still some significant differences. West Midlands Fire Service record a total of 31 applications they did not regard as satisfactory, provided by borough, but did not answer if any of these applications were allowed against their wishes. 


\subsection{Planning control responses}

- Number of applications

Twenty one out of fifty LABC were able to provide a numerical answer to this question within the scope of a FOI request. Thirteen of the numerical responses are in Greater London (43\% response rate), four in Greater Manchester (40\%), and four from the West Midlands (57\%). Seven of the numerical responses for planning consultations were given by local authorities who did not provide a numerical answer for building control consultations.

\section{- Record of consultations}

Thirty five local authorities answered this question with a Yes or No answer. Of these 95\% stated they do keep records of the consultations with the fire services. $6 \%$ of these responses (two local authorities) stated they do not keep records of advice from LFA. Seven entities were unable to answer this question within the cost/time restrictions of the Freedom of information act, and seven did not answer this specific question (one of the seven having not responded to any).

Two LAPC stated that the LFA were not consulted for planning purposes. These are discussed further in the next section.

- Questions 3 and 4. Applications meeting fire authority acceptability and application approvals against recommendations.

Twelve LAPC were able to provide numerical answers (24\% of all local authorities contacted, and $32 \%$ of those who responded to this question). The majority of these recorded zero disputes (one recorded three application issues). Twenty responded stating that answering these were too long or costly to respond. Three Local authorities responsible for planning control did not record this information, and one stated asking this was not part of the consultation process at all. Ten did not respond to these questions. Responses to these questions for the planning process were in general shorter and less detailed than those for building control, however there were again a range of responses.

Many authorities stated there were no Planning Applications that did not meet local fire service advised specifications and guidance, in the opinion of the fire service.

One stated,

"All decisions are taken having given consideration to the WMFS comments. There may be a difference of emphasis and it may be that some issues of concern to WMFS, whilst noted, cannot legitimately be addressed through Planning or Building Regulations."

This echoes the position expressed by several building control entities.

Two planning authorities stated that they did not consult the LFA on planning issues.

"Planning officers cannot recall any such applications within the last year. Planning officers are guided by Schedule 4 of the Development Management Procedure in terms of consultation, which the London fire Brigade is not on." and, 
"The Planning Development Team ...do not consult with the Fire Brigade etc at the planning stage of a development, this would occur during the Building Control process."

This stands out as, although consultation with LFAs is not always necessary, many LAPC who responded show that they are consulting on planning with the LFA, and thus clearly judge fire safety may be an issue in some scenarios.

- Fire and Local Authority data comparison.

Records of these consultations are not recorded by Fire services.

The variation in these responses has significant implications for safety provision and can be directly related to governance of fire safety in buildings. The separation of build and occupation, and the lack of fire engineering expertise required in the process have a direct effect on how decision making varies.

\subsection{Governing and enforcing consultation}

The holistic nature of fire safety assessment requires a high level of understanding of fire spread and compartmentalisation, fire stopping, firefighting, and evacuation. It is therefore difficult to separate the building design and use and yet in England and Wales, this is how building is arranged, split into building design/build; and building occupation. The LFA role in stage one is limited to consultation and there is no requirement for LABC to use this information. $\mathrm{LABC}$ decides what adherence to building regulations is, sometimes disputing or ignoring LFA advice, as demonstrated by answers received in this work through FOI. In turn, this reflects the broader transitions towards downscaling and shifting the responsibility towards local authorities as the idealized site for managing and enforcing building regulations.

There is no legislative requirement for LAPC to contact the fire service at all. This action is again discretionary. The results of this research again show that the discretionary nature planning processes result in quite different interpretations of consideration of fire safety by local authorities. A minority of local authorities have stated they rarely consult, or do not consult at all for planning processes.

As the purpose of building regulations should be to create a safe building for use, this demonstrates the problematic nature of these consultation processes, whereby some LABC discount LFA opinion as being outside of the scope of the building regulations. This suggests that either building regulations as written accept a higher level of risk than LFA (who have specific expertise in this area), or that this separation of build and use consent is hampering fire safety through the range of discretionary applications. Since building design and use are intrinsically linked, one umbrella system examining fire safety fully could be a way to stop this separation, reducing opportunities to integrate fire safety at an early stage, and where authorities have the most control. Instead, the shift towards self-regulation and shifting responsibility for regulation and enforcement to the local authority exposes the inconsistencies that are emerging in terms of consulting on fire safety. Hackitt (2018) has recommended the consent process move under such an umbrella organisation involving the local authorities, fire services and the health \& safety executives (however the involvement of fire engineers is not clear at this early stage). 


\subsection{Expertise in fire safety}

There is also seemingly little advice on who is qualified to make these assessments in relation to building regulations and fire safety. This raises concerning issues about expertise in decision making, particularly in this case where fire safe systems may be life critical. What is considered expertise and the necessity to deploy this emerges as a problematic implication of shifting responsibility and placing the onus on local authorities within the broader context of self-regulation. Rather this challenges notions of expertise as it becomes reimagined within these processes of local state restructuring.

The only reference to fire experts in the building approval process is the requirement for LFA consultation. LFA expertise is defined in a competency framework (NFCC, 2015) though this is not required by law. No other fire professionals are required in the process. LABC are advised to use third party assessment where they do not have the capability (DCLG, 2017; LFEPA, 2017), but there is no guidance on the competence they should have. It is possible that LFAs are employing experts, however, this has not been suggested as a specific option by any local authority contacted in this research work. LABCs have admitted in their responses to not insisting upon LFA recommendations, but there is no guarantee they are competent to make this judgement on fire. It is possible some local authorities are both, not using LFA advice, and not using competent internal/external fire safety advisors, which has serious implications for building safety. The potential depletion of expertise raises fundamental questions about capacity and the competency of decisions being made within a political context that has favoured downsizing and downscaling to the local state, as part of a project of local state retrenchment seeking to shift responsibilities to local authorities.

A better system of fire protection, with redundancy, would require qualified fire engineering experts to input fire advice not only at an early stage, but at several points throughout the system. This would include consultation with qualified fire engineers in the design stage, consultation with fire service, reporting to local planning/building controls (visible by public, residents, homeowners etc. allowing scrutiny) and appropriate approvals at the end. This would address some points made by Hackitt (2018) in relation to ignorance in the system. Lack of clarity on roles and responsibilities (though much of this area is in relation to the role of those designing and running the buildings), and inadequate regulatory oversight and enforcement tools. Hackitt (2018) has proposed a level of oversight throughout the building design, build and management, through a joint oversight authority involving fire and rescue services, local authority building control working together, with additional support from the Health \& Safety executive. Hackitt also proposes a series of gateway points that must be met by building duty holders to the satisfaction of the joint authority to strengthen safety systems. It would be prudent to make fire engineering qualifications a requirement of those on these technical authorities to ensure good and up-to-date oversight.

Also, while approved inspectors are audited by the Construction industry council, there does not appear to be a comparable audit process on local authority decisions, and even if there were this work suggests information may not be readily accessible. This reflects successive decades of local state restructuring, where New Labour's roll out of their Better Regulation agenda did not seek to tackle enforcement, but rather to remove the barriers placed on individuals. Whereas more recently, the post-2010 governing landscape has continued to promote a self-regulatory agenda, with the abolition of the Audit Commission reflecting the agenda to remove perceived red tape (Hodkinson, 
2018). Again, allowing fire professionals and interested public/residents/owners this ability would improve the safety underpinning. Hackitt (2018) highlights the importance of good fire safety documentation to ensure an audit trail.

The complexity of fire safety in a building, particularly large buildings such as houses of multiple occupation and high-rise buildings, means that it is unlikely that any actor other than a competent fire engineer will appreciate the impact of even minor changes to building design and yet there are no regulations or advice from central government on what constitutes a proper person to assess this. Some councils (Hammersmith and Fulham Council, 2016; Hounslow Council, 2007) state some competence level of fire risk assessors, but do not state this is used for building control, and some councils are using unregistered fire risk assessors (Barratt, 2019). As local authorities in England and Wales are both under significant pressure to fulfil housing targets, and from dramatic reduction in budget, there is a risk the discretion may not be applied safely.

Based on the information obtained in this work there does not appear to be any guarantee that competent expertise is being employed for the purpose of fire safety in building and planning processes, with the dismissal of LFA expert opinion reflecting a displacement of expertise within these processes of regulation. The reasons for the dismissal of this advice should be clearly visible for proper scrutiny but the building consent process appears largely opaque to building users. This is supported by a conclusion in Hackitt (2018) supporting transparency of information and an audit trail for decision making, enabling a "golden thread" of crucial information (with reliable and accurate reporting being key).

This is in stark contrast to some other industry areas where decisions are safety-critical and can result in the loss of life. High reliability organisations (HRO) are run to "manage and sustain almost error-free performance despite operating in hazardous conditions where the consequences of errors could be catastrophic." (HSE, 2011). HROs are characterised by active error reporting, an appreciation for complexity/context, continual technical training, and deference to expertise. Through this HROs manage to maintain safety while enabling problem identification, and adaptability. The success is highly dependent of funding (numbers, level of expertise) and an appreciation for disaster prevention work. La Porte (1996) observes, "The better an HRO is in achieving safe...the more difficult public resource overseers are to convince that resources ... should remain stable." A highly effective safety regime can be a victim of its own success. Until 2014 fire deaths in England were falling (Home Office, 2019), resulting in questions around continued funding with falling incidents (Knight, 2013). This arguably fails to value prevention work. Although the high fatality count in the year of the Grenfell Tower incident could be regarded as an anomaly (from a data perspective), compared to the 2014 figure, the number of fire fatalities has been higher for all subsequent years (a 7 to 39\% increase) following fire service cuts.

The results and findings in this work appear to culminate in exposing a lack of governance in relation to fire safety. Discretion in relation to decision-making, a lack of expertise, and separation of roles across fire safety may be making buildings less fire safe, and scrutiny of the building and planning system is currently difficult. This also makes any internal or external audit process extremely difficult, or in some cases impossible. This raises fundamental questions about the implications of the ways in which fire safety regulation and enforcement has shifted towards a self-regulatory agenda over recent decades, with a focus on placing the onus on local authorities and individuals. The broader process of local state restructuring that has unfolded as a result of both successive governments has resulted in a dramatic difference in the interpretation of the guidance, and a reorientation around and 
challenges of the notions of expertise. Building regulatory system is one of several issues affecting fire safety, and may be contributing to serious fire safety deficits.

\section{Conclusions and future work}

This paper has examined the nature of the consultation relationship between Local Fire Authorities and Local Authority Building and Planning Control for the purposes of fire safety regulation. Through a series of 53 freedom of information requests across three major metropolitan areas in England, this work has found that the current system of governance, through a combination of discretion and lack of transparency, may be allowing gaps in safety regulation and enforcement.

Building suitability is assessed by local planning and building control, with the specific approval of individual buildings occurring in the LABC. There is little guidance for local government from central government on consultation with fire experts, other than a requirement to consult with LFAs, but without guidance on how that material should be used. Only half the local government authorities approached were able to answer a simple question on the number of consultations with LFAs. For those who responded, there was a significant range of interpretations of the role and process, from total use of advice, to none. Despite the clear links, oversight of building design and guidelines adherence is separated in practice from oversight of safe building occupation and does not have to use LFA advice.

There is a lack of prescription in who is qualified to assess building guideline adherence in relation to fire safety. LFAs have NFCC guidance on qualifications but there are no specific requirements from central government. There is no specific guidance on fire safety qualifications needed within LABC to understand and assess fire safety. A better system of fire protection, with redundancy, would require qualified fire engineering experts to assess fire safety at several points throughout the system. Qualification levels could be required in an equivalent way to the requirements of medical professional qualifications. One single umbrella agency, with properly qualified individuals, providing oversight on the fire safety across development planning, building and occupation could provide a solution to the confusion identified in the current system. This is now being explored in the UK government processes though details of Fire engineering involvement are yet to be determined. This would need to be supported by rigorously tested building regulations that require products and systems to demonstrate their fire-worthiness.

There is a further discussion to be had around the level of transparency and scrutiny that these results allow, in relation to the decision-making process for fire safety in building and planning control. Is it possible to go back and reliably understand the decision making that occurred? Can the current system be interrogated to give information necessary for fire safety analysis by the public (including residents) and organisations? Not only is the lack of transparency bad for the relationship and trust between citizens and government, but as future funding is likely to be required to fill the voids identified by, inter alia, Hackitt (2018), the lack of data would be problematic and hinder an evidence-based approach. The introduction of safety measures in any industry will always involve a cost-benefit calculation, there is a need for good data to accurately assess this calculation, and a right for consumers to be able to scrutinise their housing quality and also make the same assessment in terms of their own safety. The natural conclusion of these points is to examine the risk in the system. Who assesses risk versus who bears it? Are the risks transparent to everyone in 
the system and are they being effectively managed? The results of this paper would suggest that it is likely some risks are not being fully understood or recorded but further work is required to examine the impact of this on the overall impact of a lack of transparency and risk location in the systems. This will be the subject of future work in this series.

All of the results and findings in this work appear to culminate in exposing a lack of governance in relation to fire safety. Results suggest there does not appear to be any guarantee that competent expertise is being employed for the purpose of fire safety in building/ planning processes. It appears that the combination of non-prescriptive building standards, local government authority discretion, and a lack of dictated response to fire authority advice from central government, has resulted in a post-code lottery of fire safety provision, and that stronger legislation is required to ensure expertise in the system is used to ensure safe buildings. In turn, this importantly highlights one of many issues affecting fire safety, and could be contributing to serious fire safety deficits.

A better system would require qualified fire engineering professionals to review and approve safety-critical features, as well the system being more visible and allowing scrutiny by interested parties such as residents and homeowners.

Acknowledgements The authors would like thank London South Bank University legal experts K Silver, Prof. M Weaver and Dr S Phillips, and London Fire Brigade Fire Engineers L Seal and G Steele, for valuable discussions on the legal and regulatory framework, and planning and building control processes.

Open Access This article is licensed under a Creative Commons Attribution 4.0 International License, which permits use, sharing, adaptation, distribution and reproduction in any medium or format, as long as you give appropriate credit to the original author(s) and the source, provide a link to the Creative Commons licence, and indicate if changes were made. The images or other third party material in this article are included in the article's Creative Commons licence, unless indicated otherwise in a credit line to the material. If material is not included in the article's Creative Commons licence and your intended use is not permitted by statutory regulation or exceeds the permitted use, you will need to obtain permission directly from the copyright holder. To view a copy of this licence, visit http://creativecommons.org/licenses/by/4.0/.

\section{References}

Aecom. (2012). Mapping the interfaces between building control and other regulatory regimes which impact on a building BD2733. Department for Communities and Local Government. ISBN: 978-1-4098-2900-3

Andrews, R. (2010). The impact of modernisation on fire authority performance: An empirical evaluation. Policy \& Politics, 38(4), 599-617.

Apps, P. (2017). LFB issues 51 enforcement notices against high rises post-Grenfell. https://www.insidehous ing.co.uk/home/lfb-issues-51-enforcement-notices-against-high-rises-post-grenfell-53312. 24/11/17. Accessed 01/08/18.

Bailey, N., Bramley, G., \& Hastings, A. (2015). Symposium Introduction: local reponses to 'austerity.' Local Government Studies, 41(4), 571-581.

Barratt, L. (2019). Who watches the watchers?: Councils' use of unregistered fire risk assessors revealed. Inside Housing. https://www.insidehousing.co.uk/insight/insight/who-watches-the-watchers-councilsuse-of-unregistered-fire-risk-assessors-revealed-59751

BBC News (2019). https://www.bbc.com/news/uk-40301289. Created 29/10/2019. Last accessed 24 June 2021.

Booth, R. (2017). Grenfell Tower: 16 council inspections failed to stop use of flammable cladding. Retrieved August 1, 2018, from https://www.theguardian.com/uk-news/2017/jun/21/31renfell-tower-16-councilinspections-failed-to-stop-use-of-flammable-cladding. 21/06/17. Accessed 01/08/18.

Boswell, C. (2017). The role of expert knowledge in international organizations. In A. Littoz-Monnet (Ed.) The politics of expertise in international organizations: how international bureaucracies produce and mobilize knowledge. Routledge. 
Brenner, N., Peck, J., \& Theodore, N. (2010). Variegated neoliberalization: Geographies, modalities, pathways. Global Networks, 10(2), 182-222.

Brenner, N., \& Theodore, N. (Eds.). (2002). Spaces of neoliberalism: Urban restructuring in North America and Western Europe. Blackwell.

BS 99912015 Code of practice for fire safety in the design, management and use of residential buildings. British Standards Institution.

Building Act. (1984). United Kingdom. https://www.legislation.gov.uk/ukpga/1984/55. Accessed 10/05/19.

Building Regulations. (2010). United Kingdom. Retrieved August 1, 2018, from http://www.legislation.gov. uk/uksi/2010/2214/contents/made

Building regulations and fire safety procedural guidance 2015. United Kingdom. 5th edition. Department for Communities and Local Government. https://www.labc.co.uk/sites/default/files/resource_files/proce dural_guidance_march_2015.pdf. Accessed 21/02/19.

CFPA. (2018). https://cfpa-e.eu/national-regulations/regulations-germany/. Confederation of Fire Protection Associations Europe. Last accessed 24 June 2021.

Danewid, I. (2019). The fire this time: Grenfell, racial capitalism and the urbanisation of empire. European Journal of International Relations.

DBIS. (2016). Getting government off your back: Our commitment to cutting red tape. https://www.gov.uk/ government/speeches/getting-government-off-your-back-our-commitment-to-cutting-red-tape. Created 03/03/16. Accessed 10/05/2019.

DCLG. (2013). Approved Document B. Volume 2-Buildings other than dwellinghouses. London: NBS for the Department of Communities and Local Government.

DCLG. (2015). Building Regulations and Fire Safety Procedural Guidance (5th ed.). Department for Communities and Local Government. UK.

DCLG. (2017). Building control performance standards. Department for Communities and Local Government. https://www.gov.uk/government/publications/building-control-performance-standards. Created 01/01/2017. Accessed 24/05/2019.

De Castella (2017). Retrieved March 9, 2019, from https://www.ribaj.com/intelligence/how-europe-does-itgrenfell-intelligence-tom-de-castella. Created 24/07/17. Accessed 09/03/2020.

Deas, I. (2013). Towards post-political consensus in urban policy? Localism and the emerging agenda for regeneration under the Cameron Government. Planning Practice and Research, 28(1), 65-82.

Downe, J., \& Martin, S. (2006). Joined up policy in practice? The coherence and impacts of local Government Modernisation Agenda. Local Government Studies, 32(4), 465-488.

Ellson, A. (2020). 500,000 people live in flats with unsafe cladding. The Times. https://www.thetimes.co.uk/ article/500-000-people-live-in-flats-with-grenfell-cladding-2mbjd8b2q. Last accessed 24 June 2021.

Farrugia, A. (2021) Re: Bill 178-Building and Construction Authority Act. Retrieved April 28, 2021, from https://parlament.mt/media/110842/bill-178-proposti-tal-kamra-tal-peritit.pdf. 11/02/21. Accessed 28/04/21.

Featherstone, D., Ince, A., Mackinnon, D., Strauss, K., \& Cumbers, A. (2012). Progessive localism and the construction of political alternatives. Transactions of the Institute of British Geographers, 37(2), 177-182.

Ferry, L., \& Murphy, P. (2018). What about financial sustainability of local government!-A critical review of accountability, transparency and public assurance arrangements in England during austerity. International Journal of Public Administration, 41(8), 619-629.

Fire Precautions Act 1971. United Kingdom. http://www.legislation.gov.uk/ukpga/1971/40/contents. Accessed 01/08/18.

Freedom of information Act 2000. United Kingdom. https://www.legislation.gov.uk/ukpga/2000/36/contents. Accessed 01/08/18.

Gannaway, P. (2014). http://www.frmjournal.com/frm-issues/frm-issues_detail.looking-up.html. Created 01/02/14. Accessed 10/05/19.

Greater Manchester Act 1981. United Kingdom. http://www.legislation.gov.uk/ukla/1981/9/contents/enacted. Accessed 01/08/18.

Hackitt, J. (2017). Independent review of building regulations and fire safety: Interim report. Appendix D: Mapping the building and fire safety regulatory system-high-rise residential buildings. 18 December 2017. CM9551. Secretary of State for Housing, Communities and Local Government.

Hackitt, J. (2018). Building a safer future. Independent Review of building regulations and fire safety: Final report. May 2018. CM9607. Secretary of State for Housing, Communities and Local Government.

Hammersmith and Fulham Council. (2016). https://www.lbhf.gov.uk/building-control/fire-risk-assessments. Accessed 21/02/19.

Harris, C. (2017). https://www.euronews.com/2017/12/13/ban-flammable-materials-from-europe-s-highrises-to-prevent-another-grenfell-say-experts. Created 13/12/2017. Last accessed 24 June 2021. 
Hounslow Council. (2007). http://democraticservices.hounslow.gov.uk/documents/s28220/. Created 27/06/07/. Accessed 31/07/18.

Hodkinson, S. (2019). Safe as houses: Private greed, political negligence and housing policy after Grenfell. University Press.

Hodkinson, S. (2018) Grenfell foretold: A very neoliberal tragedy. In C. Needham, E. Heins, \& J. Rees (Eds.), Social Policy review 30: Analysis and debate in social policy. Policy Press.

Home Office. (2019). Fire and rescue incident statistics. Home Office Statistical Bulletin 14/19. BN: 978-178655-858-9. UK Crown copyright 2019.

HSE. (2011). High reliability organisations. A review of the literature. RR899. Health and Safety Executive Books.

IEAust. (2017). Grenfell Tower fire highlights important need for engineers' input. https://www.engineersa ustralia.org.au/News/grenfell-tower-fire-highlights-important-need-engineers-input. 30/06/21. Accessed 28/04/21.

IFE. (2014). https://www.ife.org.uk/Fire-Risk. Created 05/03/14. Accessed 01/08/18.

Knight, S. K. (2013). Facing the Future FINDINGS from the review of efficiencies and operations in fire and rescue authorities in England London. TSO.

Jessop, B. (2002). Liberalism, neoliberalism, and urban governance: A state-theoretical perspective. Antipode, 34(3), 452-472.

Krugman, P. (2012). The austerity agenda. New York Times.

La Porte, T. R. (1996). High reliability organizations: Unlikely, demanding and at risk. Journal of Contingencies and Crisis Management, 4(2), 60-71.

Lane, B. (2018). Phase 1 report-Appendix F. Reaction to fire tests and classifications part 1.2.16. Grenfell Tower Inquiry.

Ley, A. J. (2004). Building control-An historical review. Session: CIB T5 Performance Based Buildings and Regulatory Systems 2004 (kostenlos): Building for the Future: The 16th CIB World Building Congress 2004.

LFEPA. (2017). Consultation response - Call for evidence for the independent review of building regulations and fire safety. https://www.london-fire.gov.uk/media/2844/lfb-response-independent-review-of-buildingregulations-and-fire-safety-17oct2017.pdf. Created 17/10/17. Accessed 16/05/19.

Greater London Authority. (2017). Lessons Learnt from Grenfell Tower. https://www.london.gov.uk/questions/ 2017/2935. 13/07/17. Accessed 28/04/21.

Lowndes, V., \& Pratchett, L. (2012). Local governance under the Coalition Government: Austerity, localism and the 'big society.' Local Government Studies, 38(1), 21-40.

Mayer, M. (2016). Review of resourcing of the London Fire Brigade. https://www.london.gov.uk/sites/default/ files/fire_resources_review_-_7_october_2016.pdf. 7/10/16. Accessed 31/07/18.

McIntyre, N. (2017). England's fire services suffer 25\% cut to safety officers numbers. https://www.theguardian.com/uk-news/2017/aug/29/englands-fire-services-suffer-25-cut-to-safety-officers-numbers. 29/08/17. Accessed 31/07/18.

MHCLG. (2019). https://www.gov.uk/government/uploads/system/uploads/attachment_data/file/800363/ Table_1_Building_Safety_Data_Release_April_2019.csv/preview. Created 09/05/19. Accessed 14/05/19.

Ministry of Housing, Communities and Local Government. (2018). https://www.gov.uk/guidance/compe tent-person-scheme-current-schemes-and-how-schemes-are-authorised. Created 12/03/2018. Last accessed 24 June 2021.

Moore-Bick, M. (2019). Grenfell tower inquiry: Phase 1 report overview (p. 5). https://assets.grenfelltowerin quiry.org.uk/GTI\%20-\%20Phase\%201\%20report\%20Executive\%20Summary.pdf. Accessed 09/07/2020.

Murphy, P., \& Greenhalgh, K. (2017). Modernisation, local alignment and collaboration fire and rescue services under the early new labour administrations from 1997 to 2005. In P. Murphy, \& Greenhalgh, K. (Eds.), Fire and rescue services leadership and management perspectives (pp. 9-26). Springer Nature.

Murphy, P. (2015). Briefing note on the 'impact of funding reductions on fire and rescue services': Local government report for the National Audit Office. NTU.

Murphy, P., \& Greenhalgh, P. (2013). Performance management in fire and rescue services. Public Money and Management, 33(3), 225-232.

NFCC. (2015). http://www.cfoa.org.uk/19532. Created 16/04/15. Accessed 31/07/18.

Office for National Statistics. (2020). Licensed under the Open Government Licence v.3.0. Ordnance Survey data $@$ Crown copyright and database right.

Peck, J., \& Tickell, A. (2002). Neoliberalizing space. Antipode, 34(3), 380-404.

Planning Portal. (2006). https://www.planningportal.co.uk/info/200128/building_control/38/building_regul ations/4. Created 21/05/06. Accessed 01/08/18.

Penny, J. (2017). Between coercion and consent: The politics of "Cooperative Governance" at a time of "Austerity Localism” in London. Urban Geography, 38(9), 1352-1373. 
RTPI. (2017). Responsibility for fire safety during the development application process in England (October 2017) (p. 1). Royal Town Planning Institute.

RIBA. (2017). RIBA statement on Grenfell Tower fire. https://www.architecture.com/knowledge-and-resources/ knowledge-landing-page/grenfell-tower-fire-statement. 16/07/2021. Accessed 28/04/21.

Smith, S. (1957). Not waving but drowning. Hamburg, New York: Peer Musikverlag.

Spencer, T., Hayden, J., Murphy, P., \& Glennon, R. (2018). Stating the obvious: Evaluating the state of public assurance in fire and rescue authorities in England. International Journal of Emergency Services, 8(1), $20-33$

Timmins, N., \& Gash, T. (2014). Dying to improve: The demise of the audit commission and other improvement agencies. Institute for Government.

United Kingdom Prime Minister's Office. (2017). https://www.gov.uk/government/publications/grenfell-towerinquiry-terms-of-reference-published. 15/08/17. Accessed 28/04/21.

Verzoni, A. (2017). London Calling. https://www.nfpa.org/News-and-Research/Publications-and-media/NFPAJournal/2017/September-October-2017/Features/NFPA-285. 01/08/17/. Accessed 28/04/21.

Ward, K., Newman, J., John, P., Theodore, N., MacLeavy, J., \& Cochrane, A. (2015). Whatever happened to local government? A review symposium. Regional Studies, 2(1), 435-457.

Wheeler, B. (2015). Spending review: Department by department cuts guide. https://www.bbc.co.uk/news/ukpolitics-34790102. 24/11/15. Accessed 31/07/18.

Worthy, B. (2010). More open but not more trusted? The effect of the Freedom of Information Act 2000 on the United Kingdom central government. Governance, 23(4), 561-582.

Publisher's Note Springer Nature remains neutral with regard to jurisdictional claims in published maps and institutional affiliations. 